\title{
The effect of Government investment and Private Investment on Economic Growth and Labor Absorption and Its Impact on Poverty Levels In The Province Of South Kalimantan
}

\author{
M. Ramadhan \\ Regional Government of the Province of South Kalimantan \\ Ujianto \\ Universitas 17 Agustus 1945 Surabaya \\ Mulyanto Nugroho \\ Universitas 17 Agustus 1945 Surabaya
}

\begin{abstract}
High-quality economic growth is economic growth that can encourage industrialization, can create jobs as wide as possible and can encourage the performance of other sectors more efficiently and effectively, high economic growth accompanied by efficient and effective allocation of resources can be stimulus in development to improve people's income so that it can reduce poverty. To reduce the level of poor people, of course, requires increased economic growth and equitable income distribution, rapid economic growth and not balanced with equity will lead to inequality between regions. There are several kinds of disparities that often block a society in its efforts to achieve prosperity, namely: (1) disparities between regions, (2) disparities between sectors, (3) disparities in the income distribution of the community. Studi aims to examine and analyze the effect of government investment and private investment on poverty levels through economic growth and labor absorption in South Kalimantan Province. The data analysis method used in this study is PLS to test the seven hypotheses formulated in this study. The conclusions of the results of this study are: 1) Government investment has a significant impact on economic growth. 2) Government investment does not have a significant impact on labor absorption. 3) Private investment does not have a significant impact on economic growth. 4) Private investment has a significant impact on labor absorption. 5) Economic growth has a significant impact on labor absorption. 6) Economic growth has a significant impact on reducing poverty levels. 7) Labor absorption has a significant impact on reducing poverty levels.
\end{abstract}

Key words: Government Investment, Private Investment, Economic Growth, Absorption of Labor, Poverty Levels, Disparity Of Income

\section{PRELIMINARY}

The economic development pursued by developing countries aims to achieve prosperity and prosperity for the entire community. Achieving the welfare of the community, the main problems faced by every developing country including Indonesia are unemployment, unequal distribution of income and poverty. The inability of market mechanisms in classical economic theory to answer economic problems is the starting point for the development of Keynes's thought.

The main problem of the economy is a large amount of unemployment is a strong reason for the need for government intervention (policy) which is the character of Keynes's thought. The change of thought from the classical flow which put forward the market mechanism driven by 
Adam Smith (1776) began to lose its role to be replaced by a new thought driven by John Maynard Keynes with his book The General Theory of Employment, Interest and Money (1936) which was responded by public at that time including the President of the United States of America, Richard Nixon, thus affect US economic policy.

Development is identical with economic growth which is an investment function that enables a community to continue to increase economic activity and employment opportunities (Sukimo, 2000: 367). WW growth model, Rostow (1960) emphasizes that the state can only reach the stage of take-off towards sustainable economic development driven by innovations and increased investment so that the level of increasing national income is higher than the level of population growth (Sukimo, 1985: 107). In an economy that recognizes the mechanism of interest rate transmission, the interest rate must be monitored by the government so that it is compatible with the reach of the real sector.

There is no doubt that high economic growth, in the long run, is indeed very important for the elimination/reduction of poverty levels. Kuznet's hypothesis at an early stage of development the level of poverty tends to increase and as it approaches the end of development the number of poor people will gradually decrease. Many other factors affect poverty reduction, such as economic structure, patterns of the income distribution, availability of natural resources, quality of human resources, technological mastery, investment levels, and the seriousness of the government in poverty reduction efforts (Tambunan, 2008: 172).

Regional autonomy as one of the solutions to educate the region to be more independent in having an economy that was finally able to develop the regional economy and the national economy in 1999, when UU No. 22 of 1999 was rolled out about regional autonomy, the local government system in Indonesia change a system from centralized to decentralized. A fundamental change in the order of the central and regional government, namely the great regional authority in planning, implementing, and at the same time holding the government responsibility.

The economic growth of South Kalimantan Province from 2011-2015 experienced fluctuations but did not change much in the economic structure which was divided into three main sectors of Gross Regional Domestic Product (GRDP), namely the Agriculture Sector, the Industrial Sector (Mining, Processing Industry, Electricity, Gas \& Water and Construction), and the Sector Services (Trade, Hotels \& Restaurants, Transportation \& Communication, Finance, Rentals, Corporate Services and Services). The contribution that is getting smaller is the agriculture sector. Shifts in economic structure and economic growth in South Kalimantan Province are illustrated in Table 1.1. following :

Table 1.1.

Economic Structure And Economic Growth In South Kalimantan Period 2011-2015

\begin{tabular}{|c|c|c|c|c|c|}
\hline \multirow{2}{*}{ Year } & \multicolumn{3}{|c|}{ Sector (\%) } & \multirow{2}{*}{$\begin{array}{c}\text { Total } \\
\text { (\%) }\end{array}$} & $\begin{array}{c}\text { Economic } \\
\text { Growth (\%) }\end{array}$ \\
\cline { 2 - 4 } & Agriculture & Industry & Service & (\%) & 6,49 \\
\hline 2011 & 23,40 & 39,47 & 37,07 & 100 & 5,85 \\
\hline 2012 & 22,57 & 39,87 & 37,57 & 100 & 5,53 \\
\hline 2013 & 22,60 & 39,90 & 37,60 & 100 & 5,07 \\
\hline 2014 & 22,62 & 39,92 & 37,70 & 100 & 4,49 \\
\hline 2015 & 22,65 & 39,93 & 37,75 & 100 & \\
\hline
\end{tabular}

Source : BPS- Statistics Indonesia South of Kalimantan Province (processed), 2016 
GRDP calculation through the production approach is inseparable from the role of labor which is one of the factors of production in addition to other factors of production. The Workforce Contribution of South Kalimantan Province also experienced a shift in the proportion of labor absorption in 2011, which was still dominated by the Agriculture sector, but in 2015 although it was still dominated by the agricultural sector, the industrial sector increased quite high. With economic growth that is getting better, it is expected to increase employment. In line with the increasing labor force of South Kalimantan Province, it is necessary to develop economic activities that can absorb the optimal workforce.

To reduce poverty, of course, requires increased economic growth and equitable distribution of income. Rapid economic growth and not balanced equity will lead to regional disparities (reginal disparity). Basri (1995: 92) states that there are several kinds of disparities that often hamper a society to prosper, which are: (1) disparities between regions, (2) disparities between sectors, and (3) disparities in the distribution of community income. The disparity between regions can be seen from the developed regions and the less developed regions, this is because they do not pay attention to whether the economic growth is greater or smaller the rate of population growth or changes in economic structure.

The research phenomenon above can be described in Figure 1.1 as follows:

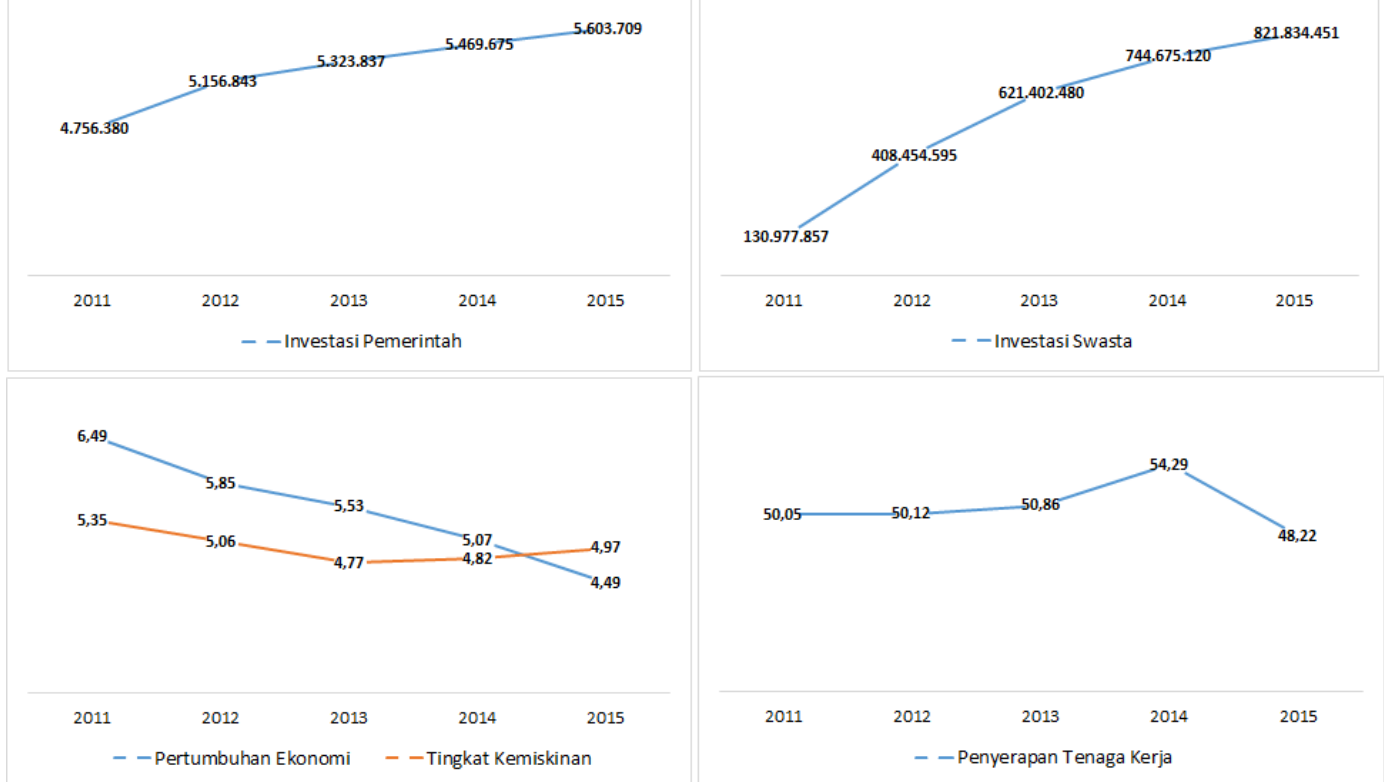

Figure 1.1 Overview of the Research Phenomenon

Figure 1.1 shows that the total government investment and private investment in all regencies/cities in South Kalimantan Province during the period 2011-2015, always increasing every year. The increase in the value of government investment and private investment turned out not to be in line with the rate of economic growth that actually tended to decline, so did the level of poverty which tended to increase in 2013-2015, although previously there was a decline, this became a big question turned out in general, increased government investment and private investment cannot increase economic growth and cannot reduce poverty. Also, the employment rate was relatively stagnant, and even dropped to $48.22 \%$ in 2015 , the lowest figure during the 2011-2015 period.

The novelty of this study with previous research lies in the use of income disparity variable as a variable that moderates the effect of economic growth and labor absorption on poverty levels, in previous studies have not been examined regarding the moderation of income disparity, there is income disparity as an independent variable. The problem of income 
disparity is one of the problems that is often faced by developing countries in carrying out economic development because not a few developing countries experiencing high economic growth begin to realize that such growth has little benefit in solving poverty problems because there is indeed a high disparity. Economic growth and high employment often fail to reduce poverty, this condition is made clear by the phenomenon in this study which is generally known to increase government investment and private investment unable to increase economic growth and employment, and unable to reduce poverty, which is due to not distinguishing regions with low income disparities and regions with high disparities.

Based on the background described, the research problem formulation is as follows:

1. Does government investment influence the regency/city economic growth in South Kalimantan Province?

2. Does private investment affect regency/city economic growth in South Kalimantan Province?

3. Does government investment affect the absorption of Regency / City labor in South Kalimantan Province?

4. Does private investment affect the absorption of Regency / City labor in South Kalimantan Province?

5. Does economic growth affect the absorption of Regency / City labor in South Kalimantan Province?

6. Does economic growth with the equitable disparity in income affect poverty levels in Regencies / Cities in South Kalimantan Province?

7. Does labor absorption by the distribution of income disparity affect the poverty rate of regencies/cities in South Kalimantan Province?

\section{THEORETICAL BASIS}

\section{Economic Growth and Economic Development}

Economic growth and development is a process shown by the government and private policies in managing existing resources and forming a partnership pattern between the government and the private sector to create new jobs and stimulate the development of economic activities (Meier, 1970: 7). The main problem in economic growth and economic development lies in the emphasis on economic growth and economic development policies that are based on the uniqueness of each region by using the potential of human resources, institutions, and physical resources locally. This development orientation leads to regional initiatives in the process of creating new employment opportunities and stimulating increased economic activity (Badrudin, 2013: 113).

\section{Definition of Investment}

In general, the investment includes the addition of goods and services in the community such as the addition of new machinery, construction of new roads and the opening of new land. The economic theory defines investment as expenditures to buy capital goods and production equipment to replace and especially adding capital goods in the economy that will be used to produce goods and services in the future (Samuelson, 2004: 137 and Sukimo, 2007: 271).

This understanding of investment reinforces what Lewis (1993: 75) has said that investment is a demand for goods and services to create or increase production capacity or income in the future. Investment is a major component in driving the economic development of a country or region. 
Increased investment will encourage trade and production volumes which in turn will expand productive employment opportunities and means that it will increase income per capita while increasing community welfare Investment is essentially a way that can be done by private or government in order to increase economic growth and in the long run can raise the standard of living of the people (Mankiw, 2003).

\section{Government Investment}

Government investment will experience a multiplier with an increase in Gross National Product (GNP) due to an increase in government spending on goods and services so that greater output increases and a large increase in investment.

According to Adolf Wagner in Soepangat (1991: 42-44) and Mursinto (2005), government spending increases from time to time because of the increase in government activities that require financing. Soepangat (1991: 52) explains that an increase in government expenditure budgets affects improving people's welfare. The provision of public goods will benefit those in need who need to be provided by the government whose financing is from capital expenditure.

\section{Private Investment}

The amount of realized investment originating from domestic investment and foreign investment in private investment.

Efforts towards equitable distribution of development among regions are also other factors taken into account by the government. The private sector does not deal specifically with these factors. Even if there is a link, nature is not direct, namely through various regulations (Azis, 1985: 15). The factors of production are often classified into four, which is land, labor, capital, and entrepreneurship. The classification of the four factors of production is based on differences in the partial supply elasticity, the characteristics contained in each factor of production, and the returns received by each owner of the factor of production.

\section{Labor and Absorption}

According to Sumarsono (2006: 7), workers are all people who are willing to be able to work, meaning that all people who carry out work activities for themselves or others without receiving wages or those who can work. According to Simanjuntak (1998), labor included is someone who takes care of the household, school, who is looking for work or is working from the age of 14-60 years.

Workers are residents who are of working age. According to Law UU No. 13 year 2003,chapter I article 1 paragraph 2 stated that labor is anyone who can do work to produce goods and or services both to meet their own needs and for the community. Broadly speaking, a country's population is divided into two groups, namely labor and not labor. The population is classified as a workforce if the population has entered the working age. The age limit that applies in Indonesia is 15 years - 64 years. According to this understanding, every person who can work is called labor. There are many opinions about the age of these workers, there are those who say that over 17 years there are those who say more than 20 years.

According to Todaro (2006: 310), Population growth and labor force growth (FK) have traditionally been considered as one of the positive factors that spur economic growth. The greater number of workers means that it will increase the level of production, while greater population growth means that the size of the domestic market is greater. However, it is still questionable whether it is true that rapid population growth will have a positive or negative impact on economic development. 


\section{Income Disparity}

The problem of income disparity is one of the problems that is often faced by various poor countries or developing countries in implementing economic development. Not a few developing countries that experienced high economic growth began to realize that such growth had little benefit in solving the problem of poverty. High economic growth often fails to reduce and even eliminate absolute poverty. Fast Gross Domestic Product (GDP) per capita growth cannot automatically improve the lives of many people, because what is called the 'trickle down effect' process of the benefits of economic growth for the poor does not happen as expected (Arsyad, 1988: 165).

The income per capita of a society that continues to increase in the long run is a result of increased economic development in the area. The aim of economic development is not merely to create a modern society, but more importantly is to create a better life for the entire community. This goal will not be achieved if economic development causes the distribution of income among the people to worsen.

\section{Poverty}

Poverty, according to the World Bank's definition in 2007, is one of the conditions in which a person cannot savour his basic needs which include health, decent standard of living, freedom of self-esteem, and a sense of respect with others. The absolute poor according to the World Bank are people who live on less than $\$ 1$ per day, medium poverty on less than $\$ 2$ a day. Poverty is a stage that must be passed in the economic development of a region and related to the inability to meet basic needs (Mikkelsen, 2003: 104).

Understanding poverty according to BPS- Statistics Indonesia is a condition of meeting basic needs that are below the minimum standard requirements, both for food and non-food that is below the poverty line (poverty line). The poverty line is calculated based on the basic needs approach, namely the amount of rupiah, which is needed to be able to meet the minimum basic food needs (2100 calories/capita/ day) and non-food items such as housing, health, education, transportation, clothing, and other goods/services. Based on the minimum needs that must be fulfilled for life, the poverty line costs are determined which are used by BPS- Statistics Indonesia to estimate the number and percentage of poor people.

The size of poverty according to Kuncoro (2006: 111) distinguishes 3 (three) groups, namely absolute poverty, relative poverty, and structural poverty. Absolute poverty is a condition in which a person's income is below the poverty line and is not enough to determine the basic needs of his life. This concept determines the minimum income level that is sufficient to meet the physical needs of food, clothing, household to ensure its survival. The main difficulty of the concept of absolute poverty is to determine the composition and level of minimum needs because these two things are not only influenced by habits but also climate, the level of progress of the country concerned and other economic factors. To live properly, a person needs goods and services to meet his physical and social needs.

\section{Population, Samples and Sampling Techniques}

Types and sources of data in this study are secondary data from 13 districts/cities from 2011 to 2015. The population as a whole unit of analysis has at least one characteristic in common (Singarimbun and Effendi, 1995: 152). Sugiono (2003: 55) defines a population as a generalization area consisting of objects/subjects that have certain quantities and 
characteristics. It can be concluded that the population is taking objects/subjects that have certain characteristics in full.

Sampling is selecting parts of elements of the population that is the subject which the measurement was carried out or called the unit of study (Emory, 1996: 214). The population of this research is all regencies/cities throughout South Kalimantan Province, amounting to 13 regencies/cities.

This research uses the census method by using the population of all districts/cities in 13 districts/cities in the South Kalimantan Province during the period 2011-2015. The data consists of 13 districts/cities and a period of 5 years so that the research data amounted to 65 data.

Secondary data used are secondary data published by BPS, Bappeda and SKPD / other agencies related to districts/cities in South Kalimantan Province and Bank Indonesia Banjarmasin from 2011 to 2015. This study uses data sourced from secondary data, namely data from 13 districts/cities in South Kalimantan Province over 5 years.

\section{DISCUSSION}

\section{The Effect of Government Investment on Economic Growth}

The role of government investment in regional development is very important in stimulating and encouraging economic growth, especially in terms of building infrastructure, procurement of facilities and public infrastructure. According to Todaro (2000: 136), one of the main components of economic growth is capital accumulation which includes all forms of investment invested in land, physical equipment, capital, and human resources. Kuznet in Arsyad (2010: 227) in line with Todaro states the economic growth of a country as an increase in the country's ability to provide economic goods for its population, increased ability and technological advancement, institutional and ideological adjustment.

The results of testing the hypothesis of the effect of government investment on economic growth, using the analysis of Partial Least Square (PLS) with the help of SmartPLS software shows the effect coefficient of 0.269 (positive) with a T-stat value greater than 1.96 (significant), which means government investment provides a positive and significant impact on increasing regional economic growth. The positive coefficient also means that the effect of government investment is in line if government investment increases, it has the potential to significantly increase economic growth.

The results of this study are consistent with the reasearch of Mursinto (2004) who concluded that development spending has a positive and significant effect on GRDP. The results of the study explain that increasing local government spending will encourage economic growth. According to Adolf Wagner in Soepangat (1991: 42-44) and Mursinto (2005b) also shows that government spending from time to time is increasing because of the increase in government activities that require financing.

\section{Effect of Government Investment on Labor Absorption}

The results of testing the hypothesis of the effect of government investment on employment, using Partial Least Square (PLS) analysis with the help of SmartPLS software shows the effect coefficient is only 0.186 (positive) with a T-stat value smaller than 1.96 (not significant), which means that government investment does not have a large impact on increasing employment. 
The results of this study are consistent with the results of research by Rostow and Musgrave in Mangkosoebroto (2001: 170) concerning the development of government spending initially providing various public facilities and infrastructure that invest in capital-intensive infrastructure that does not require a lot of labor. Government investment is mostly directed at repairing, supplying damaged capital goods, maintenance, spending on office equipment and households so that capital expenditure is not used for business expansion that can absorb labor.

The results of this study are also in line with the study of India (2012) that government investment has no significant effect because government investment is used to provide educational facilities, health facilities, and transportation facilities. Besides capital expenditure is also used on components that do not directly affect labor absorption, namely costs for equipment rental costs, planning costs, and supervision costs, licensing fees, consultant fees and other costs that do not absorb much labor.

\section{The Effect of Private Investment on Economic Growth}

Hypothesis testing results of the influence of private investment on economic growth, using Partial Least Square (PLS) analysis with the help of SmartPLS software shows the coefficient of influence is only 0.141 (positive) with a T-stat value smaller than 1.96 (not significant), which means Private investment does not have a large impact on increasing regional economic growth.

The results of this study are also consistent with Kuznet's statement in Pressman (2000: 77) that a large private investment in the mining sector comes from PMA so that investment returns are more enjoyed by foreign investors. The contribution of the results of private investment in the mining sector to the regional government is still very small compared to the central government because the local government only receives profit sharing and royalties whose value is very small so that the results cannot be used optimally and freely for regional development.

\section{Effect of Private Investment on Labor Absorption}

The results of testing the hypothesis of the effect of private investment on employment, using Partial Least Square (PLS) analysis with the help of SmartPLS software shows the effect coefficient of 0.144 (positive) with a T-stat value greater than 1.96 (significant), which means that high private investment will have a large impact on increasing employment.

Private investment invested in districts/cities in South Kalimantan Province is investment in the rubber plantation sub-sector which absorbs a lot of labor for a long time, then the palm oil sub-sector which absorbs a lot of labor since land opening, nursery, processing, planting, maintenance and harvesting similarly, investment in the animal feed industry which absorbs a lot of labor. The high absorption of labor is supported by qualify human resources and being able to access the jobs offered. The high plan and realization of investment in the plantation sub-sector have an important role in absorbing labor, likewise, the coal mining sector is also quite large absorbing labor. However, the other problem is the high in-migration from outside the area to work in the mining sector and the plantation sector so that it becomes the main competitor of the local workforce. When the regional economy declines the amount of inward migration to get work, the impact will be the consequences of unemployment which will then become a burden on the region. 


\section{Effect of Economic Growth on Labor Absorption}

Hypothesis testing results regarding economic growth towards labor protection, using Partial Least Square (PLS) analysis with the help of SmartPLS software showed a growth coefficient of 0.209 (positive) with a T-stat value greater than 1.96 (significant), which means increasing, high economic growth will provide a large growth in increasing labor absorption.

Development input factors are labor, capital, land, and technology, labor as a potential component. With the economy running normally, the economy can develop and have an impact. Economic growth improves the distribution of income and welfare by expanding employment opportunities and productivity. The available employment opportunities encourage specialization and increase productivity.

\section{Effects of Income Disparity Moderation on the Effect of Economic Growth on Poverty Rate}

The results of testing the hypothesis of the effect of income disparity moderation on the effect of economic growth on poverty levels, using Partial Least Square (PLS) analysis with the help of SmartPLS software shows the magnitude of the interaction effect is 0.082 with a T-statistics value smaller than 1.96 (not significant), so it can be concluded that income disparity does not moderate the effect of economic growth on poverty levels, this shows that the magnitude of the effect of economic growth on poverty levels is the same, both in districts /cities with low or high-income disparities.

The results of this study are consistent with the results of Susanto's (2012) research on income disparities in Indonesia. The big problem facing developing countries like Indonesia is the disparity in income distribution and poverty levels, the unequal distribution of income has the potential to trigger the emergence of poverty problems. This opinion is consistent with the results of this study that there is a weakening effect of economic growth on poverty levels in areas with high-income disparities.

Safitri, R.I. (2015) in her research on economic growth, income disparity, and poverty also stated that economic growth and income disparity had a significant effect on poverty levels. However, economic growth turned out to have a positive effect on poverty levels, this could be due to high-income inequality.

\section{Effects of Income Disparity Moderation on the Effect of Labor Absorption on Poverty Levels}

The results of testing the hypothesis of the effect of moderating income disparity on the effect of labor absorption on poverty levels, using Partial Least Square (PLS) analysis with the help of SmartPLS software shows the magnitude of the effect of the interaction of labor absorption and income disparity on poverty levels is 0.384 with T-statistics greater than 1.96 (significant), so it can be concluded that income disparity moderates the effect of labor absorption on poverty levels, this shows that the magnitude of the effect of labor absorption on poverty levels is different in districts/cities with low-income disparities and districts with high-income disparity.

The results of this study are consistent with the results of research by Suhariyanto et al. (2015) regarding poverty, employment and income distribution analysis. The results of this study indicate that poverty, unemployment, and inequality in various fields are three main problems that need to be considered in measuring the level of development of a region. High economic growth will only be meaningful if followed by equitable distribution of development outcomes which in turn will reduce the number of unemployed and poverty levels. The economic growth 
of regencies/cities in South Kalimantan shows good performance at a macro level, but on the other hand, the reality of poverty, unemployment, and income inequality still surrounds most people. By observing the structure of economic growth, the researchers assessed that economic growth in South Kalimantan Province has not been of good quality so that economic growth has no connection and does not have a positive impact on poverty reduction, especially in areas with high-income disparities.

\section{CONCLUSION}

Based on the analysis of the results of studies and discussions on the effects of government investment and private investment on economic growth, employment and poverty levels in districts/cities in South Kalimantan Province, the following are the conclusions:

1. Government investment has a positive and significant effect on economic growth in districts/cities in South Kalimantan Province, a positive coefficient is significant if government investment increases, economic growth will also increase significantly.

2. Government investment does not have a significant effect on employment in regencies/cities in South Kalimantan Province, meaning that higher government investment does not have a large impact on increasing employment.

3. Private investment does not have a significant effect on economic growth in regencies/cities in South Kalimantan Province, meaning that higher private investment does not have a large impact on increasing economic growth.

4. Private investment has a positive and significant effect on employment in districts/cities in South Kalimantan Province, a positive coefficient means that if private investment increases, employment will also increase significantly.

5. Economic growth has a positive and significant effect on employment in regencies/cities in South Kalimantan Province, a positive coefficient means that if economic growth increases, employment will also increase significantly.

6. Income disparity does not moderate the effect of economic growth on poverty levels, this shows that the magnitude of the effect of economic growth on poverty levels is the same, both in districts/cities with low-income disparities or in districts/cities with high-income disparities.

7. Income disparity moderates the effect of labor absorption on poverty levels, this shows that the magnitude of the effect of labor absorption on poverty levels is different in districts/cities with low-income disparities and districts with high-income disparities. The positive moderation coefficient shows that income disparity weakens the negative effect of labor absorption on poverty levels so that employee can only reduce poverty levels in districts/cities with low-income disparities, whereas in districts/cities with high-income disparities, increased absorption the workforce has no effect on reducing poverty.

\section{SUGGESTION}

Based on the conclusions results of studies on the effect of government investment and private investment on economic growth, employment and poverty levels in districts/cities in South Kalimantan Province, the research recommendations are as follows:

1. Based on the results of the analysis shows that government spending, tends to directly influence economic growth, while private investment tends to affect labor absorption. This indicates that government spending is a very strong variable affecting economic growth to reduce poverty levels in the Province of South Kalimantan. Thus, this government investment should be prioritized in efforts to increase economic growth to reduce poverty levels in districts / cities in South Kalimantan Province. 
2. The strategy to reduce poverty levels in districts/cities in South Kalimantan Province must be carried out by increasing labor absorption through increasing the realization of private investment, both foreign and domestic, to increase labor absorption so that it contributes to reducing poverty. Increasing private investment will increase labor absorption, which in turn will reduce poverty.

3. The regional government is expected to increase investment in domestic investment foreign investment through policies to maintain regional economic, political and security stability, improve infrastructure facilities and infrastructure that support and facilitate regulations in investing to increase employment opportunities which ultimately reduces poverty.

4. Government investment also needs to be directed towards increasing human capital investment through improving the quality of health and education as an important policy in local government strategies to increase economic growth and reduce poverty.

5. For future research, this research is expected to provide information and literature on the effects of government investment, private investment, economic growth, employment, income disparity, and poverty levels at the district/city level. Future research can increase the number of variables that can also be used as a material for consideration in predicting poverty levels, such as variables related to technological development in the hope that it can further enrich the content and scope of research, because current technological developments change the structure of the economy, so that each region must also anticipate technological development is a good opportunity to increase economic growth and increase employment, so poverty rates are expected to decrease. Furthermore, income disparity in an area is also noteworthy because it is proven that labor absorption is only able to reduce poverty levels in areas with lowincome disparities, whereas in regions with high-income disparities, the effect of labor absorption on poverty levels is small.

\section{References}

Abd. Rachim $A F, H, 2005$, Pengaruh Struktur Pendapatan dan Belanja Pemkot Terhadap Kemandirian Wilayah dan Perkembangan Kegiatan Sosial Ekonomi Masyarakat Kota Samarinda, PPS, Unair Surabaya.

Abdullah, Syukriy, dan Abdul Halim, 2006, Studi atas Belanja Modal pada Anggaran Pemerintah Daerah dalam Hubungannya dengan Belanja Pemeliharaan dan Sumber Pendapatan, Jurnal Akuntansi Pemerintah, Volume 2 No. 2, November.

Acemoglu, D. and Robinson, J.A. 2002. The Political Economy of The Kuznets Curve. Review of Development Economics, Vol. 6 No. 2: 183-203.

Adams, R. H. (2003). Economic Growth, Inequality, and Povery: Finding from A New Data Set. Policy Research Working Paper 2972. World Bank. February.

Adams, Ricahrd H. Jr, 2003. Ecoomic Growth, Inequalitym and Poverty: Finding from a New Data Set. Policy Research Working Paper \#972. Word Bank. February.

Keynes, JM, 1936, The General Theory of Employment, Interest and Money, New York Harcourt Brace

Kuncoro, Mundrajat, 2010, Ekonomika Indonesia, UPP STIM YPKN, Yogyakarta

Rostow, WW, 1991, The Stage Economic, 3 ed, hal 37-38

Safitri, R.I, 2015, Pertumbuhan ekonomi, ketimpangan pendapatan, dan kemiskinan: analisis data provinsi di Indonesia 2010-2013. IPB Scientific Repository, No. 2166.

Suhariyanto, K., A. Avenzora, dan Y. Karyono, 2015, Analisis Kemiskinan, Ketenagakerjaan, dan Distribusi Pendapatan, BPS Indonesia Jakarta.

Todaro, M. 2006. Pembangunan Ekonomi, Edisi 9. Penerbit Erlangga. Jakarta

Wurarah, RN, 2011, Pengaruh Belanja Modal terhadap Pertumbuhan Ekonomi, dan Penyerapan TK serta Kesejahteraan Masyarakat di Prov PapuaBarat, Disertasi, PPS Unair Surabaya 
Ramadhan, M., Ujianto., \& Nugroho, M. (2019). The effect of Government investment and Private Investment on Economic Growth and Labor Absorption and Its Impact on Poverty Levels In The Province Of South Kalimantan. Archives of Business Research, 7(10), 145-156.

Zhang Tao and Heng Fu, Zou, 1998, Fiscal Desentralization, Public Spending and Economic Growth in China, Journal of Public Economic, 67 pp 221-240 